\title{
Zonguldak Orman Bölge Müdürlüğü Çalışanlarının İş Doyumunu Etkileyen Faktörler
}

\author{
İsmet DAŞDEMIR ${ }^{1 *}$, Ayşegül AĞDAŞ OKUL ${ }^{2}$ \\ ${ }^{1}$ Bartın Üniversitesi Orman Fakültesi, Orman Mühendisliği Bölümü, 74100, Bartın. \\ ${ }^{2}$ Bartın Orman İşletme Müdürlüğü, 74100, Bartın.
}

\section{Öz}

Bu çalışma, Zonguldak Orman Bölge Müdürlüğü ve bağlı birimlerinde çalışanların iş doyumunu etkileyen faktörleri belirlemek, iş doyumunun bazı kişisel özelliklere (çalışılan birim, görev, eğitim, yaş, cinsiyet, medeni hal vb.) göre farklılığını denetlemek ve böylece çalışanların iş doyumun artırılmasına katkı yapmak amacıyla ele alınmıştır. Araştırma verileri üç bölümden (Kişisel Özellikler Bölümü - 12 soru, İş Doyum Bölümü - 43 soru, Öneriler ve Yorumlar Bölümü) oluşan bir anket formu yardımıyla elde edilmiştir. Anket formları 2018 yılında Zonguldak Orman Bölge Müdürlüğü ve bağlı birimlerinde çeşitli görevlerde çalışan 348 personel üzerinde, tam alanda, e-maille, yüz yüze görüşme yöntemiyle ve çalıştıkları işletme müdürlüklerine elden teslim edilerek uygulanmıştır. Elde edilen veriler betimleyici istatistikler, Faktör Analizi ve Kruskal-Wallis H-Testi ile değerlendirilmiştir. Değerlendirme sonucunda, çalışanların iş doyumunu etkileyen en önemli faktörler; (1) Kararlara katılım ve saygınlık, (2) İşle bütünleşme, (3) Liyakate dayalı örgüt kültürü, (4) Örgütsel iletişim (bildirişme), (5) Vicdanen rahatlık, (6) Çalışma koşulları, (7) Ödül-takdir ve terfi olanağı olarak saptanmıştır. Ayrıca çalışanların orta düzeyde iş doyumuna sahip oldukları ve toplam iş doyumunun görev yapılan birime, medeni hale, eşin çalışma durumuna ve vekalet göreve göre istatistiksel olarak anlamlı fark gösterdiği, buna karşılık göreve, eğitime, yaşa, cinsiyete, doğum yerine, toplam hizmet süresine, görevde geçen süreye ve görev yeri sayısına göre anlamlı bir fark göstermediği belirlenmiştir. Çalışma sonunda, Zonguldak Orman Bölge Müdürlüğü ve bağlı birimlerinde çalışanların iş doyumunun, veriminin ve başarısının artırılmasına yönelik birtakım değerlendirmeler ve öneriler yapılmıştır.

Anahtar Kelimeler: İş doyumu, iş doyumunu etkileyen faktörler, kişisel özellikler, Zonguldak Orman Bölge Müdürlüğü.

\section{Factors Affecting Job Satisfaction of Employees in the Zonguldak Regional Directorate of Forestry}

\begin{abstract}
This study aims to determine the factors affecting job satisfaction of employees in the Zonguldak Regional Directorate of Forestry and its affiliated units, to check the differences of job satisfaction according to some individual features (task unit, position of duty, education, age, gender, marital status, etc.), and thus, to contribute to increasing job satisfaction of employees. The research data were obtained by a questionnaire consisting of three parts (Individual Features Section-12 questions; Job Satisfaction Section-43 questions; Suggestions and Comments Section). The questionnaire forms were applied in 348 staff working at in various positions in the Zonguldak Regional Directorate of Forestry and its affiliated units, in full field, by e-mail, face-to-face interview method and delivered to the enterprise directorates by hand in 2018. Descriptive statistics, Factor Analysis and Kruskal-Wallis H-Test were used to evaluate the data. As a result of the evaluation, the most important factors affecting the job satisfaction of employees were determined as (1) Participation in decisions and respect, (2) Integration with job, (3) Merit-based organizational culture, (4) Organizational communication, (5) Conscientious comfort, 6) Working conditions, 7) Award-appreciation and promotion opportunity. It was also determined that employees had medium job satisfaction and that total job satisfaction was statistically significant difference according to the task unit, marital status, working status of the spouse and proxy duty. However, it was determined that total job satisfaction did not show a significant difference according to the position of duty, education, age, gender, place of birth, total service duration, duty duration and number of duty place. At the end of the study, some evaluations and suggestions were made to increase the job satisfaction, productivity and success of the employees in the Zonguldak Regional Directorate of Forestry and its affiliated units.
\end{abstract}

Keywords: Job satisfaction, factors affecting job satisfaction, individual features, Zonguldak Regional Directorate of Forestry. 


\section{Giriş}

Çalışanların iş yerlerinden ve yaptıkları işten sağladıkları memnuniyet düzeyinin ve bunu etkileyen faktörlerin bilinmesi, yönetimin amaçlarına ulaşması ve başarılı olması için son derece önemlidir. O nedenle günümüzde tüm kurumlarda iş doyumu çalışmaları değer kazanmıştır. Bu konuda yapılan araştırmalar genellikle kişinin işinden sağladığı iş doyumunun ölçülmesine, iş doyumunu etkileyen faktörlerin belirlenmesine ve iş doyumunu kişisel özelliklere göre farklı olup olmadığının incelenmesine dayanmaktadır.

İş doyumu, çalışma yaşamının en önemli konularından biri olup, kurumların başarısı, iş doyumu yüksek çalışanlara bağlıdır. İş doyumu da yönetsel başarıyı etkileyen önemli bir faktördür. İnsan bir kaynak olarak görülmeye başladığından bu yana, iş doyumu çalışma yaşamında ve insan kaynaklarında öne çıkan konularından biri olmuştur (İncir, 1990). İş doyumu, davranış bilimciler ve araştırmacılar tarafından değişik biçimlerde tanımlanmıştır. Eren (1996) iş doyumunu, işten elde edilen maddi çıkarlar ile işçinin beraberce çalışmaktan zevk aldığı iş arkadaşları ve eser meydana getirmenin sağladığı bir mutluluk olarak tanımlar. Akkamış (2010) ise iş doyumunu, iş görenlerin iş ve iş tecrübelerini değerlendirme sonuçlarına karşı kullandıkları hoşa giden, olumlu duygusal ifadeler olarak tanımlamıştır. Başka bir tanımda ise, iş doyumu kişilerin işlerinden duydukları memnuniyet ya da memnuniyetsizlik durumu olarak ifade edilmiştir (Davis, 1981'e atfen Çıtak vd., 2008). Yukarıdaki tanımlar ve bu makale kapsamında elde edilen bulgular dikkate alınarak, daha ayrıntılı ve kapsamlı bir şekilde $i$ ş doyumu; "çalışanın işle bütünleşmesi, yaptığı işi sevmesi, işine bağlanması, özverili çalışması, işin insanlığa faydalı olması ve kişiye saygınlık kazandırması, iş yeri ve çalışma koşullarının, ücret ve sosyal hakların yeterliliği sonucunda ortaya çıkan, bir taraftan iş verimliliğini artıran diğer taraftan kişiye faydalar sağlayan, kişinin işinden ve iş yerinden duyduğu memnuniyet düzeyi” şeklinde tanımlanmıştır.

İş görenlerin niteliği ve performansı işletmelerin başarısını etkileyen en önemli ve değişkenliği en yüksek faktörlerin başında gelmektedir. Yoğun rekabet koşulları, iş görenlerin etkin ve verimli şekilde çalışmalarını zorunlu kılmaktadır. Bu zorunluluk, iş görenlerin iş doyumlarının sağlanmasına verilen önemi artırmaktadır. Çünkü çalışanların verimli bir şekilde çalışabilmeleri için iş koşullarından memnun olmaları gerekir (Yılmaz vd., 2009). İş doyumsuzluğu; kişinin yaptığı işten hoşlanmamasına, işe karşı bıkkınlık, işini sevmeme, işten kaçma isteği ve iş arkadaşlarıyla anlaşmazlık duymasını ifade eder. İş doyumsuzluğu kişiyi olumsuz duygulara sevk eder. İş doyumsuzluğu çalışanda yoğun ve sürekli kaygı yaratmakta, onun ruh sağlı̆̆ını olumsuz etkilemektedir (Aksu vd., 2002).

Hemen her örgütte çalışanların iş doyumu üzerine çeşitli çalışmalar yapılmaktadır. Orman kaynaklarının toplumsal yaşamadaki yeri ve önemi nedeniyle, ormancılık örgütünde çalışanların iş doyum düzeylerinin ve iş doyumuna etkileyen faktörlerin belirlenmesi ve iş doyumlarının artırılmasına yönelik önerilerin geliştirilmesi önemlidir. Türkiye'de devlet mülkiyeti ve yönetiminde olan ormancılık örgütünün yapısı, merkez ve taşra teşkilatı yöneticilerinin iş ile ilgili tutumları, örgütsel beklentiler, çalışma koşulları, motivasyon, yapılan işin özelliği, alınan ücret vb. pek çok faktör çalışanların iş doyumunu etkilemektedir. Bu kapsamda daha önce bazı çalışmalar (Yılmaz ve Koçak, 2008; Yılmaz vd., 2009; Akyüz vd., 2011; Çok vd., 2017, Bozkurt vd., 2018) yapılmasına rağmen, Zonguldak Orman Bölge Müdürlüğü ve bağlı birimlerinde daha önce böyle bir çalışma yapılmamıştır.

Dolayısıyla bu çalışma Zonguldak Orman Bölge Müdürlüğü ve bağlı birimlerinde (Zonguldak, Devrek, Dirgine, Ereğli, Yenice, Bartın, Ulus, Karabük, Safranbolu Orman İşletmeleri, Gökçebey Orman Fidanlığı) çalışanların iş doyumunu etkileyen faktörleri belirlemek, iş doyumunun bazı kişisel özelliklere (çalışılan birim, görev, eğitim, yaş, cinsiyet, medeni hal, eşin çalışma durumu, doğum yeri, toplam hizmet süresi, görevde geçen süre, görev yeri sayısı, vekalet görevi) göre farklılığını denetlemek ve böylece çalışanların iş doyum düzeylerinin artırılmasına katkı yapmak amacıyla ele alınmıştır. $\mathrm{Bu}$ araştırmadan elde edilen sonuçlar, ormancılık teşkilatında iş doyumu araştırmalarına, ileriye yönelik bilgi birikiminin oluşmasına ve orman kaynakları yönetim sürecine olumlu katkılar sağlayacaktır.

\section{Materyal ve Metot}

\section{Araştırma Alanı}

$\mathrm{Bu}$ çalışması, Zonguldak Orman Bölge Müdürlüğü (ZOBM) ve bağlı birimlerinde (Zonguldak, Devrek, Dirgine, Ereğli, Yenice, Bartın, Ulus, Karabük, Safranbolu Orman İşletmeleri, Gökçebey Orman Fidanlığı) yürütülmüştür (Şekil 1). ZOBM'nin çalışma alanı toplam 936.063,6 ha olup, bunun \%63'ü (592.017,9 ha) ormanlık alan ve geriye kalan \%37'si (344.045,7 ha) açıklık alandır (ZOBM, 2017). 


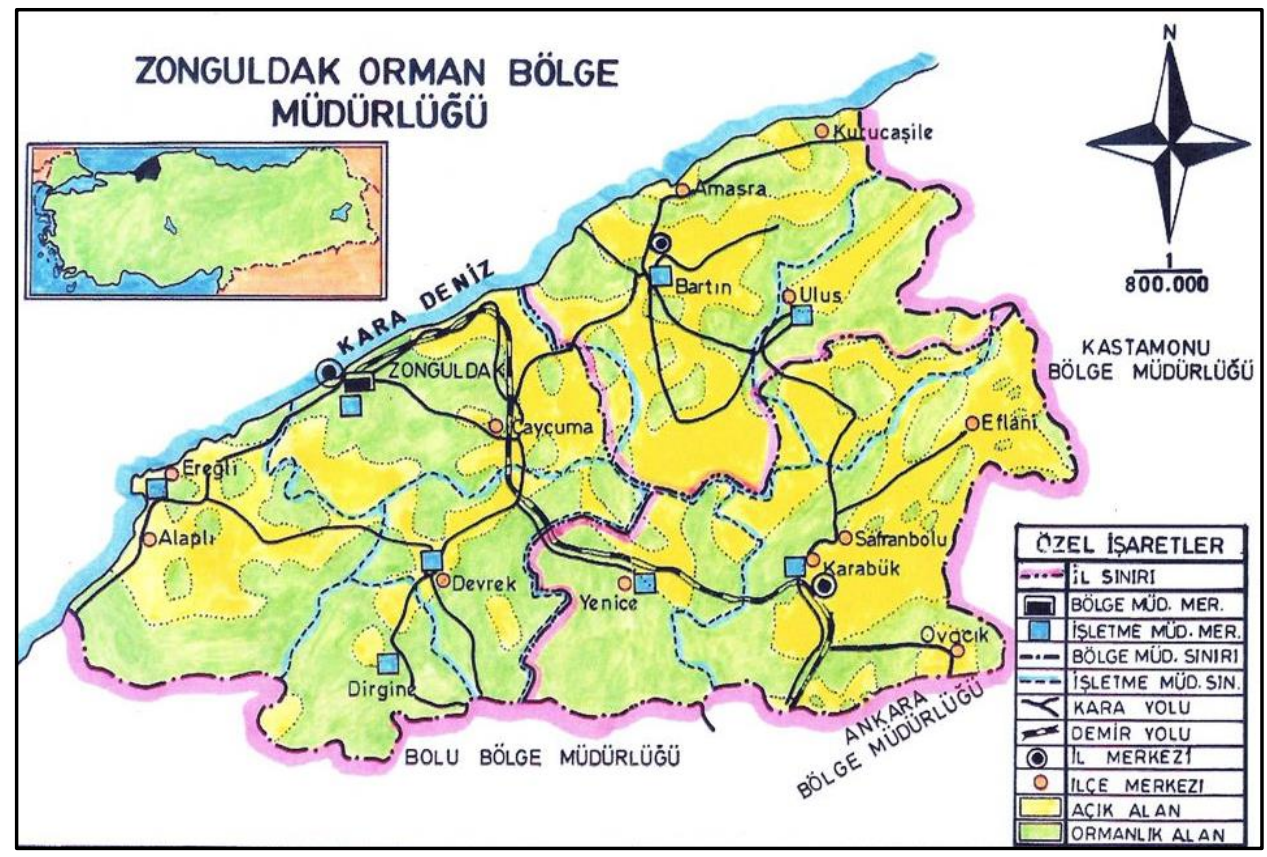

Şekil 1. Zonguldak Orman Bölge Müdürlüğü çalışma alanı (ZOBM, 2017).

\section{Araştırma Verileri ve Değerlendirme}

Araştırma verileri üç bölümden (Kişisel Özellikler Bölümü - 12 soru, İş Doyum Bölümü - 43 soru, Öneriler ve Yorumlar Bölümü) oluşan bir anket formu yardımıyla elde edilmiştir. Anket formunun birinci bölümünde çalışanların kişisel özelliklerine (çalışılan birim, görev, eğitim, yaş, cinsiyet, medeni hal, eşin çalışma durumu, doğum yeri, toplam hizmet süresi, görevde geçen süre, görev yeri sayısı, vekalet görevi) ilişkin 12 soru, ikinci bölümünde; çalışanların iş doyumunu belirlemeye yönelik olarak Minnesota İş Doyumu anketi ve 5'li "Likert Ölçeğì" esas alınarak geliştirilen 43 soru yer almaktadır. Üçüncü bölümde ise çalışanların iş doyumunun artırılmasına ilişkin önerileri ve yorumları yer almaktadır.

Anket formları 2018 yılında uygulanmıştır. Araştırmanın yapıldığı yılda ZOBM ve bağlı birimlerinde çeşitli görevlerde (müdür, müdür yardımcısı, şef, mühendis, büro personeli, arazi elemanı ve diğer) çalışan personel sayısı toplamı 635'dir. İş doyum anket çalışmasının tam alanda (tam sayım) ve tüm personel üzerinde yapılması planlanmıştır. Ancak gerçekleşen ve geri dönüşümü sağlanan anket sayısı 348 olmuştur (geri dönüşüm oranı 348/635*100=\%55'dir). Dolayısıyla anket çalışması 2018 yılında Zonguldak Orman Bölge Müdürlüğü ve bağlı birimlerinde çeşitli görevlerde çalışan 348 kişi üzerinde, tam alanda, e-maille, yüz yüze görüşme yöntemiyle ve çalıştıkları işletme müdürlüklerine elden teslim edilerek uygulanmıştır.

Araştırma verilerinin değerlendirilmek için betimleyici istatistikler (yüzde, aritmetik ortalama ve standart sapma), Faktör Analizi ve Kruskal-Wallis H-Testi kullanılmıştır (Daşdemir, 2019). İş Doyum Anketinde yer alan 43 sorunun her biri birer değişken kabul edilerek, toplam 43 değişken tanımlanmış ve bu değişkenler kullanılarak, iş doyumunu etkileyen faktörleri saptamak için Faktör Analizi uygulanmıştır. Çalışanların toplam iş doyumunun kişisel özelliklere göre farklılığını denetlemek için de Kruskal-Wallis H-Testi ile kullanılmıştır. Verilerin analizinde Excel-2010 ve SPSS (24.0 version) programlarından yararlanılmıştır.

\section{Bulgular ve Tartışma}

\section{Çalışanların Iş Doyumuna IIlişkin Genel Bulgular}

Zonguldak Orman Bölge Müdürlüğü ve bağlı birimlerinde çalışanların, iş doyum düzeylerini belirlemek için geliştirilen 43 soruluk ankette, her bir soruya 5'li Likert Ölçeğine (1-Hiç memnun değilim, 2-Az memnunum, 3Orta düzeyde memnunum 4-Fazla memnunum 5-Çok Fazla memnunum) göre verdikleri cevapların dağılımları Tablo 1'de gösterilmiştir. 
Tablo 1. İş doyumu ölçeğindeki sorulara verilen cevaplara ilişkin bilgiler.

\begin{tabular}{|c|c|c|c|c|c|c|c|c|c|c|c|c|c|}
\hline \multirow{2}{*}{\multicolumn{2}{|c|}{ Sorular* }} & \multicolumn{2}{|c|}{1} & \multicolumn{2}{|c|}{2} & \multicolumn{2}{|c|}{3} & \multicolumn{2}{|c|}{4} & \multicolumn{2}{|c|}{5} & \multirow[b]{2}{*}{$\bar{x}$} & \multirow[b]{2}{*}{$\mathbf{S}$} \\
\hline & & \multirow{2}{*}{$\begin{array}{l}\mathrm{n} \\
14\end{array}$} & \multirow{2}{*}{$\frac{\%}{4}$} & \multirow{2}{*}{$\begin{array}{c}\mathrm{n} \\
70\end{array}$} & \multirow{2}{*}{$\frac{\%}{20,1}$} & \multirow{2}{*}{$\frac{\mathrm{n}}{131}$} & \multirow{2}{*}{$\frac{\%}{37,6}$} & \multirow{2}{*}{$\frac{\mathrm{n}}{87}$} & \multirow{2}{*}{$\begin{array}{l}\% \\
25\end{array}$} & \multirow{2}{*}{$\frac{n}{46}$} & \multirow{2}{*}{$\begin{array}{c}\% \\
13,2\end{array}$} & & \\
\hline $\mathrm{S} 1$ & $\begin{array}{l}\text { İşimin yeteneklerimi kullanma ve geliştirme } \\
\text { fırsatı tanımasından }\end{array}$ & & & & & & & & & & & 3,23 & 1,04 \\
\hline $\mathrm{S} 2$ & $\begin{array}{l}\text { İşimin bilimsel ve teknik yöntemleri kullanma } \\
\text { olanağı vermesinden }\end{array}$ & 23 & 6,6 & 69 & 19,8 & 128 & 36,8 & 93 & 26,7 & 35 & 10,1 & 3,14 & 1,06 \\
\hline S3 & $\begin{array}{l}\text { İşimde benden beklenenlerin açıkça } \\
\text { tanımlanmış olmasından }\end{array}$ & 13 & 3,7 & 52 & 14,9 & 149 & 42,8 & 111 & 31,9 & 23 & 6,6 & 3,23 & 0,91 \\
\hline S4 & $\begin{array}{l}\text { İșimin anlamlı ve insanlığa faydalı olmasından } \\
\text { İșimi yaparken doğruluğuna inandığım șeyleri }\end{array}$ & 7 & 2 & 14 & 4 & 76 & 21,8 & 129 & 37,1 & 122 & 35,1 & 3,99 & 0,96 \\
\hline S5 & $\begin{array}{l}\text { söyleme ya da yapma özgürlüğümün } \\
\text { olmasından }\end{array}$ & 19 & 5,5 & 42 & 12,1 & 116 & 33,3 & 93 & 26,7 & 78 & 22,4 & 3,49 & 1,13 \\
\hline S6 & $\begin{array}{l}\text { İssimle ilgili aldığım kararları uygulamaya } \\
\text { koyabilmekten }\end{array}$ & 15 & 4,3 & 63 & 18,1 & 110 & 31,6 & 105 & 30,2 & 55 & 15,8 & 3,35 & 1,08 \\
\hline S7 & $\begin{array}{l}\text { İșimle ilgili kararlarda düşüncelerime önem } \\
\text { verilmesinden }\end{array}$ & 24 & 6,9 & 46 & 13,2 & 103 & 29,6 & 130 & 37,4 & 45 & 12,9 & 3,36 & 1,08 \\
\hline S8 & $\begin{array}{l}\text { İşiminin benden sonraki çalışma arkadaşlarıma } \\
\text { yol gösterme olanağı sunmasından }\end{array}$ & 17 & 4,9 & 46 & 13,2 & 105 & 30,2 & 110 & 31,6 & 70 & 20,1 & 3,49 & 1,10 \\
\hline S9 & $\begin{array}{l}\text { İşimin iş arkadaşlarımı çalışmaya teşvik } \\
\text { etmesinden }\end{array}$ & 22 & 6,3 & 43 & 12,4 & 115 & 33 & 113 & 32,5 & 55 & 15,8 & 3,39 & 1,09 \\
\hline S10 & İşimin başarı duygusu tattırmasından & 19 & 5,5 & 41 & 11,8 & 108 & 31 & 124 & 35,6 & 56 & 16,1 & 3,45 & 1,07 \\
\hline S11 & $\begin{array}{l}\text { İșimle ilgili yükselme olanaklarının mevcut } \\
\text { olmasından }\end{array}$ & 69 & 19,8 & 52 & 14,9 & 81 & 23,3 & 110 & 31,6 & 36 & 10,3 & 2,98 & 1,29 \\
\hline S12 & $\begin{array}{l}\text { İş yerimde alınan kararların ve yapılan } \\
\text { değişikliklerin zamanında bana iletilmesinden }\end{array}$ & 34 & 9,8 & 74 & 21,3 & 101 & 29 & 107 & 30,7 & 32 & 9,2 & 3,08 & 1,13 \\
\hline S13 & $\begin{array}{l}\text { İs yerimde üstlerimle kolay iletişim ve diyalog } \\
\text { kurulabilmekten }\end{array}$ & 19 & 5,5 & 51 & 14,7 & 76 & 21,8 & 130 & 37,4 & 72 & 20,7 & 3,53 & 1,14 \\
\hline S14 & $\begin{array}{l}\text { İş yerimde astlarımla iyi iletişim ve diyalog } \\
\text { kurabilmekten }\end{array}$ & 12 & 3,4 & 28 & 8 & 66 & 19 & 143 & 41,1 & 99 & 28,4 & 3,83 & 1,04 \\
\hline S15 & İs yerimde hiyerarşiye önem verilmesinden & 36 & 10,3 & 38 & 10,9 & 89 & 25,6 & 112 & 32,2 & 73 & 21 & 3,43 & 1,23 \\
\hline S16 & $\begin{array}{l}\text { İş yerimde liyakate önem verilmesinden } \\
\text { Isş yerimdeki yükseltme ve yer değiştirme }\end{array}$ & 39 & 11,2 & 61 & 17,5 & 97 & 27,9 & 113 & 32,5 & 38 & 10,9 & 3,14 & 1,17 \\
\hline S17 & $\begin{array}{l}\text { kriterlerinin/sisteminin adil, makul ve mantıklı } \\
\text { olmasından }\end{array}$ & 84 & 24,1 & 64 & 18,4 & 109 & 31,3 & 59 & 17 & 32 & 9,2 & 2,69 & 1,26 \\
\hline S18 & $\begin{array}{l}\text { İş yerimde sorumlulukların yerine getirilip } \\
\text { getirilmediğinin denetlenmesinden }\end{array}$ & 40 & 11,5 & 64 & 18,4 & 104 & 29,9 & 96 & 27,6 & 44 & 12,6 & 3,11 & 1,19 \\
\hline S19 & $\begin{array}{l}\text { İş yapilırken herkesin kendi üzerine düşen } \\
\text { sorumluluğu yerine getirmesinden }\end{array}$ & 56 & 16,1 & 72 & 20,7 & 124 & 35,6 & 63 & 18,1 & 33 & 9,5 & 2,84 & 1,18 \\
\hline S20 & $\begin{array}{l}\text { Teşkilatın ve işimin benden beklediklerini } \\
\text { yerine getirebilmekten }\end{array}$ & 19 & 5,5 & 29 & 8,3 & 108 & 31 & 129 & 37,1 & 63 & 18,1 & 3,54 & 1,05 \\
\hline S21 & Çalışma saatlerinin düzenli olmasından & 39 & 11,2 & 49 & 14,1 & 77 & 22,1 & 121 & 34,8 & 62 & 17,8 & 3,34 & 1,24 \\
\hline S22 & $\begin{array}{l}\text { Çalışma saatlerinin özel yaşamımın gereklerini } \\
\text { yerine getirmeme olanak vermesinden }\end{array}$ & 44 & 12,6 & 72 & 20,7 & 87 & 25 & 87 & 25 & 58 & 16,7 & 3,12 & 1,27 \\
\hline $\mathrm{S} 23$ & $\begin{array}{l}\text { İşimin yoğun çalışmayı gerektirmesi ve beni } \\
\text { her zaman meşgul etmesinden }\end{array}$ & 67 & 19,3 & 44 & 12,6 & 91 & 26,1 & 106 & 30,5 & 40 & 11,5 & 3,02 & 1,29 \\
\hline S24 & İșimin çalışma kapasiteme uygun olmasından & 22 & 6,3 & 25 & 7,2 & 107 & 30,7 & 128 & 36,8 & 66 & 19 & 3,55 & 1,07 \\
\hline S25 & $\begin{array}{l}\text { İşimin bana toplumda saygın bir kişi olma şansı } \\
\text { vermesinden }\end{array}$ & 27 & 7,8 & 29 & 8,3 & 97 & 27,9 & 129 & 37,1 & 66 & 19 & 3,51 & 1,13 \\
\hline S26 & İşimde vicdani bir sorumluluk taşımaktan & 18 & 5,2 & 28 & 8 & 76 & 21,8 & 144 & 41,4 & 82 & 23,6 & 3,70 & 1,08 \\
\hline S27 & İşimin garantili bir gelecek sağlamasından & 18 & 5,2 & 21 & 6 & 97 & 27,9 & 111 & 31,9 & $\begin{array}{c}10 \\
1\end{array}$ & 29 & 3,74 & 1,10 \\
\hline S28 & İşimde başkaları için bir şeyler yapabilmekten & 10 & 2,9 & 34 & 9,8 & 109 & 31,3 & 114 & 32,8 & 81 & 23,3 & 3,64 & 1,03 \\
\hline S29 & $\begin{array}{l}\text { Yaptığım iş karşılığında aldığım ücretten ve } \\
\text { sahip olduğum özlük haklarından }\end{array}$ & 42 & 12,1 & 54 & 15,5 & 111 & 31,9 & 87 & 25 & 54 & 15,5 & 3,16 & 1,22 \\
\hline S30 & $\begin{array}{l}\text { Yaptığım iş karşıllığında uygulanan ödül-teşvik } \\
\text { ve takdir sisteminden }\end{array}$ & 88 & 25,3 & 53 & 15,2 & 116 & 33,3 & 55 & 15,8 & 36 & 10,3 & 2,71 & 1,29 \\
\hline S31 & Üstlerimin çalışmalarıma değer vermesinden & 29 & 8,3 & 78 & 22,4 & 104 & 29,9 & 96 & 27,6 & 41 & 11,8 & 3,12 & 1,14 \\
\hline S32 & $\begin{array}{l}\text { Teşkilata ve işime bağlı olduğumu } \\
\text { hissetmekten }\end{array}$ & 15 & 4,3 & 29 & 8,3 & 93 & 26,7 & 133 & 38,2 & 78 & 22,4 & 3,66 & 1,05 \\
\hline S33 & Teşkilatın beklentilerimi karşılıyor olmasından & 26 & 7,5 & 49 & 14,1 & 129 & 37,1 & 101 & 29 & 43 & 12,4 & 3,25 & 1,08 \\
\hline S34 & $\begin{array}{l}\text { Teşkilatta belirli aralıklarla yapılan yer/görev } \\
\text { değişikliğinden }\end{array}$ & 61 & 17,5 & 68 & 19,5 & 124 & 35,6 & 73 & 21 & 22 & 6,3 & 2,79 & 1,15 \\
\hline S35 & İşimde denetlenmekten ve izlenmekten & 35 & 10,1 & 48 & 13,8 & 93 & 26,7 & 123 & 35,3 & 49 & 14,1 & 3,30 & 1,17 \\
\hline S36 & İş yerimdeki fiziki çalışma koşullarından & 41 & 11,8 & 55 & 15,8 & 97 & 27,9 & 117 & 33,6 & 38 & 10,9 & 3,16 & 1,18 \\
\hline S37 & $\begin{array}{l}\text { İşimin eğitim ve ilgi alanlarıma uygun } \\
\text { olmasından }\end{array}$ & 44 & 12,6 & 37 & 10,6 & 104 & 29,9 & 118 & 33,9 & 45 & 12,9 & 3,24 & 1,19 \\
\hline S38 & $\begin{array}{l}\text { İşimin benliğime ve kişisel düşüncelerime } \\
\text { uygun olmasından }\end{array}$ & 38 & 10,9 & 54 & 15,5 & 86 & 24,7 & 116 & 33,3 & 54 & 15,5 & 3,27 & 1,22 \\
\hline S39 & İş yerindeki hizmet içi eğitimlerden & 35 & 10,1 & 80 & 23 & 109 & 31,3 & 64 & 18,4 & 60 & 17,2 & 3,10 & 1,23 \\
\hline S40 & İş yerindeki değer yargılarından (örgüt kültürü) & 46 & 13,2 & 68 & 19,5 & 105 & 30,2 & 72 & 20,7 & 57 & 16,4 & 3,07 & 1,26 \\
\hline S41 & $\begin{array}{l}\text { İșimin sağladiğı diğer haklardan ve sosyal } \\
\text { olanaklardan }\end{array}$ & 47 & 13,5 & 66 & 19 & 105 & 30,2 & 91 & 26,1 & 39 & 11,2 & 3,03 & 1,20 \\
\hline S42 & $\begin{array}{l}\text { Üst yöneticilerin yardım, destek ve yol } \\
\text { gösterici tutumlarından }\end{array}$ & 35 & 10,1 & 58 & 16,7 & 93 & 26,7 & 116 & 33,3 & 46 & 13,2 & 3,23 & 1,18 \\
\hline S43 & $\begin{array}{l}\text { İş arkadaşlarımın yardım, destek ve yol } \\
\text { gösterici tutumlarından }\end{array}$ & 14 & 4 & 25 & 7,2 & 87 & 25 & 154 & 44,3 & 68 & 19,5 & 3,68 & 0,99 \\
\hline Topl & m İş Doyumu & & & & & & & & & & & 141,68 & 26,27 \\
\hline Soru & Başına İș Doyumu & & & & & & & & & & & 3.29 & 1,14 \\
\hline
\end{tabular}

Zonguldak Orman Bölge Müdürlüğü ve bağlı birimlerdeki çalışan 348 katılımcının, 43 sorunun her birine 1-5 
arasında verdikleri puanların ortalamalarının toplamına göre, toplam iş doyumu $141,68 \pm 26,27$ puan $(\bar{x} \pm \mathrm{S})$

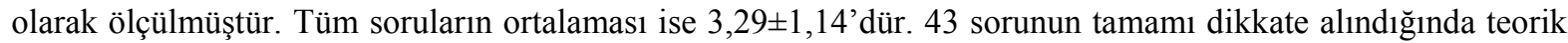
olarak 43-215 arasında beklenen toplam iş doyumu puanı aşağıdaki gibi;

1. Düşük Düzeyde İş Doyumu: 43-100 arası puan,

2. Orta Düzeyde İş Doyumu: 101-158 arası puan,

3. Yüksek Düzeyde İş Doyumu: 159-215 arası puan

üçlü seviye sınıflamasına ayrılmış ve buna göre çalışanların orta düzeyde iş doyuma sahip oldukları saptanmıştır. İş doyum ölçeğindeki 43 sorudan en yüksek ortalama puan alan ilk üç soru şunlardır;

1. İşimin anlamlı ve insanlığa faydalı olmasından (4. soru; $\bar{x}=3,99)$

2. İş yerimde astlarımla iyi iletişim ve diyalog kurabilmekten (14. soru ; $\bar{x}=3,83$ )

3. İşimin garantili bir gelecek sağlamasından (27. soru ; $\bar{x}=3,74)$

En düşük ortalama puan alan sorular ise şunladır;

1. İş yerimdeki yükseltme ve yer değiştirme kriterlerinin/sisteminin adil, makul ve mantıklı olmasından (17. soru; $\bar{x}=2,69$ ).

2. Yaptığım iş karşılığında uygulanan ödül-teşvik ve takdir sisteminden (30. soru; $\bar{x}=2,71$ )

3. Teşkilatta belirli aralıklarla yapılan yer/görev değişikliğinden (34. soru; $\bar{x}=2,79$ )

O halde iş doyumunu artırmada en yüksek puan alan sorularda memnuniyet düzeyinin korunması ve en düşük puan alan sorularda ise memnuniyet düzeyini artırıcı yönde önlemlerin alınması gerekmektedir.

\section{Çalışanların İş Doyumunu Etkileyen Faktörlerin Belirlenmesi}

Çalışanların iş doyumunu etkileyen faktörleri belirlemek amacıyla faktör analizi uygulanmıştır. Bu amaçla 43 soruluk İş Doyumu Anketinden elde edilen bilgiler veri olarak kullanılmıştır. 2018 yılında Zonguldak Orman Bölge Müdürlüğü ve bağlı birimlerinde çalışan 348 çalışan üzerinde uygulanan 43 sorunun her biri birer değişken olarak tanımlanmıştır. Böylece 43 sütun ve 348 satırdan oluşan veri matrisi faktör analizinin ilk girdisini oluşturmuştur.

Toplam 43 ölçekli değişken setinin Kaiser-Meyer-Olkin (KMO) katsayısı 0,849>0,60 ve Bartlett Sphericity Testi sonuçları $\left(\chi^{2}=5803,995\right.$; sig. $\left.=0,000<0,05\right)$ anlamlı çıktığı için, kullanılan değişkenlerin faktör analizine uygun olduğu anlaşılmıştır (Büyüköztürk, 2015). Kurallara uygun şekilde gerçekleştirilen faktör analizinde, faktör communalite değeri 0,5'den küçük olan S3, S4, S10, S16, S20, S24, S25, S31, S32, S33, S41, S42 ve S43 değişkenleri ölçekten çıkarılarak, kalan 30 değişkenle nihai faktör analizi yapılmıştır.

Faktör türetme metotlarından Principal Component ve rotasyon yöntemlerinden Varimax yöntemi kullanılarak, faktör yükü 1'den büyük olan faktörler türetilmiştir (Kaiser kriteri). Buna göre toplam varyansın \%67,40’1nı açıklayan 7 ortak faktör türetilmiştir. Elde edilen ilk 7 faktöre ilişkin rotasyon öncesi ve sonrası varyans değerleri Tablo 2'de verilmiştir. Türetilen ilk faktör en önemlisi olup, rotasyon sonucu faktörlerin varyansa katılma yüzdeleri sırasıyla; $\% 14,75, \% 10,84, \% 9,33, \% 8,98, \% 8,39, \% 8,09$ ve $\% 7,02$ olarak bulunmuştur. Rotasyon sonrası iş doyumunu etkileyen en önemli faktörler, her bir faktörü oluşturan değişkenler, faktör yükleri ve her bir faktörün açıkladığı varyans miktarları Tablo 3'te verilmiştir. Ortak faktörleri adlandırılmak ve yorumlanmak için, mutlak değer olarak 0,5'den büyük olan faktör yükleri dikkate alınmış (Bennet ve Bowers, 1977; Mucuk, 1978; Daşdemir, 1996) ve bu değerden küçük olan faktör yükleri Tablo 3 ’te gösterilmemiştir.

Tablo 2. Faktör analiziyle türetilen faktörler ve açıklanan varyans.

\begin{tabular}{|c|c|c|c|c|c|c|}
\hline \multirow{2}{*}{ Faktör } & \multicolumn{3}{|c|}{ İlk Varyansa Katılım } & \multicolumn{3}{|c|}{ Rotasyon Sonunda Varyansa Katılım } \\
\hline & Toplam & Varyans Yüzdesi & Birikimli Yüzde & Toplam & Varyans Yüzdesi & Birikimli Yüzde \\
\hline 1 & 8,69 & 28,98 & 28,98 & 4,42 & 14,75 & 14,75 \\
\hline 2 & 3,93 & 13,09 & 42,07 & 3,25 & 10,84 & 25,58 \\
\hline 3 & 2,13 & 7,11 & 49,18 & 2,80 & 9,33 & 34,91 \\
\hline 4 & 1,55 & 5,17 & 54,36 & 2,69 & 8,98 & 43,89 \\
\hline 5 & 1,40 & 4,65 & 59,01 & 2,52 & 8,39 & 52,28 \\
\hline 6 & 1,34 & 4,45 & 63,46 & 2,43 & 8,09 & 60,38 \\
\hline 7 & 1,18 & 3,93 & 67,40 & 2,11 & 7,02 & 67,40 \\
\hline
\end{tabular}


Tablo 3. Çalışanların iş doyumunu etkileyen faktörler.

\begin{tabular}{|c|c|c|c|c|}
\hline \multirow{2}{*}{$\begin{array}{l}\text { Soru } \\
\text { No }\end{array}$} & \multirow{2}{*}{ Faktörler/Değişkenler } & \multirow{2}{*}{$\begin{array}{l}\text { Faktör } \\
\text { Yükü }\end{array}$} & \multicolumn{2}{|c|}{$\begin{array}{l}\text { Açıklanan } \\
\text { Varyans }\end{array}$} \\
\hline & & & Miktar & $\%$ \\
\hline & Faktör 1: Kararlara Katılım ve Saygınlık & & 4,42 & 14,75 \\
\hline S6 & İşimle ilgili aldığım kararları uygulamaya koyabilmekten & 0,78 & & \\
\hline S8 & $\begin{array}{l}\text { İşimin benden sonraki çalışma arkadaşlarıma yol gösterme olanağı } \\
\text { sunmasından }\end{array}$ & 0,75 & & \\
\hline S7 & İșimle ilgili kararlarda düşüncelerime önem verilmesinden & 0,73 & & \\
\hline S1 & İşimin yeteneklerimi kullanma ve geliştirme firsatı tanımasından & 0,68 & & \\
\hline S2 & İşimin bilimsel ve teknik yöntemleri kullanma olanağ 1 vermesinden & 0,67 & & \\
\hline $\mathrm{S} 12$ & $\begin{array}{l}\text { İş yerimde alınan kararların ve yapılan değişikliklerin zamanında bana } \\
\text { iletilmesinden }\end{array}$ & 0,66 & & \\
\hline S9 & İşimin iş arkadaşlarımı çalışmaya teşvik etmesinden & 0,60 & & \\
\hline & Faktör 2: İşle Bütünleşme & & 3,25 & 10,84 \\
\hline S38 & İşimin benliğime ve kişisel düşüncelerime uygun olmasından & 0,79 & & \\
\hline S37 & İsimin eğitim ve ilgi alanlarıma uygun olmasından & 0,75 & & \\
\hline S35 & İşimde denetlenmekten ve izlenmekten & 0,69 & & \\
\hline S36 & İş yerimdeki fiziki çalışma koşullarından & 0,66 & & \\
\hline S39 & İş yerindeki hizmet içi eğitimlerden & 0,56 & & \\
\hline & Faktör 3: Liyakate Dayalı Örgüt Kültürü̈ & & 2,80 & 9,33 \\
\hline $\mathrm{S} 18$ & $\begin{array}{l}\text { İş yerimde sorumlulukların yerine getirilip getirilmediğinin } \\
\text { denetlenmesinden }\end{array}$ & 0,75 & & \\
\hline S17 & $\begin{array}{l}\text { İs yerimdeki yükseltme ve yer değiştirme kriterlerinin/sisteminin adil, } \\
\text { makul ve mantıklı olmasından }\end{array}$ & 0,63 & & \\
\hline $\mathrm{S} 40$ & İs yerindeki değer yargılarından (teşkilat kültürü) & 0,62 & & \\
\hline S19 & $\begin{array}{l}\text { İş yapılırken herkesin kendi üzerine düşen sorumluluğu yerine } \\
\text { getirmesinden }\end{array}$ & 0,59 & & \\
\hline & Faktör 4: Örgütsel İletişim (Bildirişme) & & 2,69 & 8,98 \\
\hline S14 & İş yerimde astlarımla iyi iletişim ve diyalog kurabilmekten & 0,82 & & \\
\hline S13 & İş yerimde üstlerimle kolay iletişim ve diyalog kurulabilmekten & 0,78 & & \\
\hline S15 & İş yerimde hiyerarşiye önem verilmesinden & 0,57 & & \\
\hline S5 & $\begin{array}{l}\text { İşimi yaparken doğruluğuna inandığım şeyleri söyleme ya da yapma } \\
\text { özgürlügümün olmasından }\end{array}$ & 0,55 & & \\
\hline & Faktör 5: Vicdanen Rahatlık & & 2,52 & 8,39 \\
\hline S26 & İşimde vicdani bir sorumluluk taşımaktan & 0,75 & & \\
\hline S29 & Yaptığım iş karşılığında aldığım ücretten ve sahip olduğum özlük & 0,70 & & \\
\hline $\mathrm{S} 28$ & İşimde başkaları için bir şeyler yapabilmekten & 0,70 & & \\
\hline S27 & İşimin garantili bir gelecek sağlamasından & 0,67 & & \\
\hline & Faktör 6: Çalıșma Koșulları & & 2,43 & 8,09 \\
\hline $\mathrm{S} 22$ & $\begin{array}{l}\text { Çalışma saatlerinin özel yaşamımın gereklerini yerine getirmeme olanak } \\
\text { vermesinden }\end{array}$ & 0,86 & & \\
\hline $\mathrm{S} 21$ & Çalışma saatlerinin düzenli olmasından & 0,82 & & \\
\hline $\mathrm{S} 23$ & $\begin{array}{l}\text { İşimin yoğun çalışmayı gerektirmesi ve beni her zaman meşgul } \\
\text { etmesinden }\end{array}$ & 0,74 & & \\
\hline & Faktör 7: Ödül-Takdir ve Terfi Olanağı & & 2,11 & 7,02 \\
\hline $\mathrm{S} 30$ & Yaptığım is karsılığında uygulanan ödül-tesvik ve takdir sisteminden & 0,70 & & \\
\hline S34 & Teșkilatta belirli aralıklarla yapılan yer/görev değișikliğinden & 0,69 & & \\
\hline S11 & İşimle ilgili yükselme olanaklarının mevcut olmasından & 0,51 & & \\
\hline & & TOPLAM & 20,22 & 67,40 \\
\hline
\end{tabular}

Tablo 3'te faktör analizi sonucunda elde edilen her bir faktör, içerdiği değişkenler ve faktör yükleri dikkate alınarak aşağıdaki gibi adlandırılmış ve yorumlanmıştır:

Buna göre, Faktör 1'in yapısında pozitif faktör yüküne sahip olan S6, S8, S7, S1, S2, S12 ve S9 değişkenleri yer almaktadır. Bu değişkenler çalışanların işiyle ilgili kararlar alması, kararlarını uygulayabilmesi, kararlarına önem verilmesi, alınan kararlardan haberdar edilmesi yeteneklerini, bilimsel ve teknik yöntemleri kullanabilmesi, işinin yol göstermesi ve teşvik etmesi gibi kişinin işiyle ilgili konularda kararlara katılımı ve saygınlık görmesiyle ilgilidir. Kararlara katılım ve saygınlık arttıkça iş doyumu da artmaktadır. Kavak üreticileri üzerinde yapılan benzer bir çalışmada (Bozkurt vd., 2018) bu özellikler "kendini kanıtlamak" ve "saygı görmek" şeklinde iki ayrı faktör altında saptanmıştır. Yılmaz vd. (2009) tarafından Mersin Orman Bölge Müdürlüğünde yapılan bir çalışmada ise bu özelliklerin bir kısmı "yönetime katılım ve terfi olanağı”, bir kısmı da "bağımsızlık-yaratıcılık-saygınlık” faktörü altında toplanmıştır. Dolayısıyla Faktör 1'in yapısında yer alan bu değişkenlerin ortak özellikleri çalışanların işiyle ilgili konularda karar alması, uygulaması ve saygınlık 
görmesiyle ilgili olduğu için, söz konusu faktör "kararlara katılım ve saygınlık" şeklinde adlandırılmış ve yorumlanmıştır.

Faktör 2; pozitif faktör yüküne sahip olan S38, S37, S35, S36 ve S39 değişkenlerinden oluşmaktadır. Bu değişkenler işin, çalışanın benliğine, kişisel düşüncelerine, eğitimine, ilgi alanına uygun olması ve iş yeri çalışma koşullarının, hizmet içi eğitimlerin ve yapılan denetimlerin uygunluğu ile ilgilidir. Yani bu faktör içinde yer alan değişkenlerin ortak özelliği, çalışanının işini, iş yerini, iş yerindeki uygulamaları sevmesi, benimsemesi ve dolayısıyla işine bağlılığını ve işiyle bütünleşmesini ifade etmektedir. Çalışanların işine bağlı olması ve işiyle bütünleşmesi iş doyumunu artırmaktadır. Dolayısıyla Faktör 2'in yapısında yer alan bu değişkenlerin ortak özellikleri dikkate alınarak söz konusu faktör "işle bütünleşme" şeklinde adlandırılmış ve yorumlanmıştır. Benzer şekilde bu konuda yapılan bir çalışmada (Daşdemir, 1998) ise; bu faktör "örgüte ve işe bağlılık" şeklinde adlandırılmış ve orman işletmelerinde yönetsel ve örgütsel başarıyı etkileyen ikinci derecede önemli bir faktör olduğu saptanmıştır.

Faktör 3'ün yapısında S18, S17, S40 ve S19 değişkenleri vardır. Bu değişkenler iş yerinde çalışanların sorumluklarını bilmesi ve yerine getirmesi, sorumlulukların denetlenmesi, adil, makul ve mantıklı yer değiştirme ve yükselme sistemi ve iş yerindeki değer yargılarıyla (kültür) ilişkilidir. Yani faktörün yapısında iş yerinde liyakate dayalı bir çalışma ortamını veya örgüt kültürünü tanımlayan özellikler yer almaktadır. Bu özelliklere sahip bir iş yerinde veya çalışma ortamında çalışanların iş doyumu artmaktadır. Dolayısıyla Faktör 3'ün yapısında yer alan bu değişkenlerin ortak özellikleri dikkate alınarak, söz konusu faktör "liyakate dayalı örgüt kültürü"” şeklinde adlandırılmış ve yorumlanmıştır.

Faktör 4, S14, S13, S15 ve S5 değişkenlerinden oluşmaktadır. Bu değişkenler iş yerinde çalışanların astlarıyla ve üstleriyle iyi iletişim ve diyalog kurmaları, bu anlamda hiyerarşik olarak örgüt içinde iletişim kanallarının açık olması ve çalışanların doğruluğuna inandığı şeyleri söyleme veya yapma özgürlüğüyle ilgilidir. İş yerinde çalışanların astları ve üstleri ile iyi iletişim içinde olması, yatay ve dikey yönde bilgi iletişiminin sağlanması, görevleriyle ilgili konularda düşüncelerini söyleme veya yapma olanağının olması çalışanların huzurlu ve verimli bir ortam içinde çalışmasına ve böylece iş doyumunun artmasına neden olacaktır. $\mathrm{O}$ halde, bu faktörü “örgütsel iletişim (bildirişme)” şeklinde adlandırmak ve yorumlamak mümkündür. Örgütsel iletişim veya bildirişme; aslında örgüt içinde çalışanlar arasında bağlantı kurma sürecidir (Tosun, 1981). Bildirişme sayesinde, örgüt içinde sorunların ve gereksinimlerin bilinmesi ve çözülmesi, çalışanların birbiri ile iyi anlaşması, karar alma ve uygulama süreçlerinin etkin işlemesi, kararlara katılması, huzurlu ve verimli bir çalışma ortamının oluşması sağlanır, böylece çalışanların iş doyumu ve başarısı artar. Benzer şekilde bu konuda yapılan bir çalışmada (Daşdemir, 1998); bildirişmenin orman işletmelerinde yönetsel ve örgütsel başarıyı etkileyen bir faktör olduğu saptanmıştır.

Faktör 5'in yapısında S26, S29, S28, S27 değişkenleri yer almaktadır. Bu değişkenler, aslında çalışanların topluma faydalı olabilmek ve işini en iyi şekilde yapabilmek amacıyla görevlerini vicdani sorumluluk içeresinde yapması, başkaları için bir şeyler yapabilmesi, alınan ücretten ve işin garantili bir gelecek sağlamasından vicdanen rahat olmasıyla ilişkilidir. Çalışanlar görevlerini yaparken topluma faydalı olduklarını vicdanen hissettikçe iş doyumu artmaktadır. Bu nedenle F5; "vicdanen rahatlık" şeklinde adlandırılmış ve yorumlanmıştır. Benzer şekilde bu konuda; Mersin Orman Bölge Müdürlüğünde yapılan bir çalışmada (Yılmaz vd., 2009); "vicdanen rahatlık", çalışanların iş doyumunu etkileyen üçüncü derece önemli bir faktör olarak saptanmıştır.

Faktör 6, anlamlı pozitif faktör yüküne sahip S22, S21, S23 değişkenlerinden oluşmaktadır. Bu değişkenler, iş yeri çalışma saatlerinin düzenli olması, özel yaşamın gereklerini yerine getirmeye olanak vermesi ve iş yoğunluğu ile ilgilidir. Bu özellikler topluca değerlendirildiğinde bu faktörün planlı çalışma koşulları ve işin özelliği ile ilgili olduğu anlaşılmaktadır. İşin zamansal planlamasının kişinin sosyal ve ailevi yaşamını da aksatmadan sürdürmesine imkân vermesi ve yapılan işin kişiye zevk verecek bir yoğunlukta olması iş doyumunu artırmaktadır. Çalışanların işine devamlılığı, bağlılığı, işini çekici bulması ve verimliliği için iş doyumu önemli bir unsurdur (Akyüz vd., 2011). Dolayısıyla bu faktör "çalışma koşullarl" şeklinde adlandırılmış ve yorumlanmıştır. Nitekim Mersin Orman Bölge Müdürlüğünde yapılan bir çalışma (Yılmaz vd., 2009) ve Muğla Orman Bölge Müdürlüğünde yapılan bir araştırmada (Akyüz vd., 2011) çalışma koşullarının çalışanların iş doyumunu etkileyen önemli bir faktör olduğu saptanmıştır.

Faktör 7'nin yapısında S30, S34 ve S11 değişkenleri yer almaktadır. Bu faktör iş karşılığında uygulanan ödülteşvik ve takdir sistemi ile işle ilgili olarak belirli aralıklarla yapılacak yer değiştirme ve terfi olanaklarını kapsamaktadır. Çalışanlara yapılan iş karşılığında objektif ölçütlere bağlı olarak uygulanan ödül, takdir ve terfi sistemi onların iş verimini ve iş doyumu artıracaktır. Dolayısıyla Faktör 7'nin yapısında yer alan bu 
değişkenlerin ortak özellikleri dikkate alınarak söz konusu faktör, “ödül-takdir ve terfi olanăğ” şeklinde adlandırılmış ve yorumlanmıştır. Aynı şekilde, bu konuda Elazı̆̆ Orman Bölge Müdürlüğünde yapılan benzer bir çalışmada (Çok vd., 2017), çalışanların iş doyumu ile takdir ve ödüllendirme yöntemleri arasındaki ilişkileri incelenmiş ve genellikle yetersiz olduğu saptanmıştır. Yılmaz vd. (2009) tarafindan Mersin Orman Bölge Müdürlüğünde yapılan bir çalışmada ise iş doyumunu etkileyen "yönetime katılım ve terfi olanağı" şeklinde bir faktör belirlenmiştir.

Böylece Zonguldak Orman Bölge Müdürlüğü çalışanlarının iş doyumunu etkileyen en önemli faktörler ile faktörlerin kapsadığı değişkenler ve ağırlıkları topluca Tablo 4’te verilmiştir.

Tablo 4. Zonguldak Orman Bölge Müdürlüğü çalışanlarının iş doyumunu etkileyen faktörler.

\begin{tabular}{clcc}
\hline Faktör No & Faktör Adı & Faktörün Kapsadığı Değişkenler & Faktör A ̈̆ırlığı (\%) \\
\hline 1 & Kararlara Katılım ve Saygınlık & S6, S8, S7, S1, S2, S12, S9 & 14,75 \\
2 & İşle Bütünleşme & S38, S37, S35, S36, S39 & 10,84 \\
3 & Liyakate Dayalı Örgüt Kültürü & S18, S17, S40, S19 & 9,33 \\
4 & Örgütsel İletişim (Bildirişme) & S14, S13, S15, S5 & 8,98 \\
5 & Vicdanen Rahatlık & S26, S29, S28, S27 & 8,39 \\
6 & Çalışma Koşulları & S22, S21, S23 & 8,09 \\
7 & Ödül-Takdir ve Terfi Olanağı & S30, S34, S11 & 7,02 \\
\hline \multicolumn{2}{r}{ TOPLAM } \\
\hline
\end{tabular}

\section{İş Doyumunun Kişisel Özelliklere Göre Farklılığının Denetimi}

Zonguldak Orman Bölge Müdürlüğü ve bağlı birimlerinde çalışanların iş doyumunun bazı kişisel özelliklere (çalışılan birim, görev, eğitim, yaş, cinsiyet, medeni hal, eşin çalışma durumu, doğum yeri, toplam hizmet süresi, görevde geçen süre, görev yeri sayısı, vekalet görevi) göre farklı olup olmadığı Kruskal-Wallis H-Testi ile denetlenmiştir ve farklı grupları ortaya koymada Duncan Testinin parametrik olmayan modifikasyonundan yararlanılmıştır (Kalıpsız, 1988; Özdamar, 2002) (Tablo 5).

Tablo 5. Toplam iş doyumunun bazı kişisel değişkenlere göre farklılığının denetimi.

\begin{tabular}{|c|c|c|c|c|c|c|c|}
\hline \multirow{3}{*}{ Değişkenler } & \multicolumn{2}{|c|}{$\begin{array}{c}\text { Kruskal-Wallis H- } \\
\text { Testi Sonuçları } \\
\end{array}$} & \multirow{2}{*}{\multicolumn{3}{|c|}{$\begin{array}{l}\text { Duncan Testi ile Farklılık Denetimi } \\
\text { (Gruplar ve gruplar içinde sıralamalar önem } \\
\text { derecesine göredir) }\end{array}$}} & \multirow{3}{*}{$\bar{X}$} & \multirow{3}{*}{$\mathbf{N}$} \\
\hline & \multirow{2}{*}{$\begin{array}{l}\text { Khi-kare } \\
\text { Değeri }\end{array}$} & \multirow[b]{2}{*}{ SD } & & & & & \\
\hline & & & No & Grup Elemanları & $\begin{array}{c}\text { İş } \\
\text { Doyumu }\end{array}$ & & \\
\hline \multirow{3}{*}{ 1. Çalışılan Birim } & \multirow{3}{*}{$25,72 * *$} & \multirow{3}{*}{8} & 1 & Yenice & Düşük & 131,75 & 32 \\
\hline & & & 2 & $\begin{array}{l}\text { Ulus, Bartın, Zonguldak, Dirgine, } \\
\text { Safranbolu, Karabük }\end{array}$ & Orta & 141,74 & 257 \\
\hline & & & 3 & Ereğli, Devrek & Yüksek & 150,51 & 59 \\
\hline \multirow{2}{*}{ 2. Medeni Hal } & \multirow{2}{*}{$5,72 *$} & \multirow{2}{*}{1} & 1 & Bekar & Düşük & 133,41 & 58 \\
\hline & & & 2 & Evli & Yüksek & 143,76 & 290 \\
\hline \multirow{2}{*}{ 3. Eşin Çalışma Durumu } & \multirow{2}{*}{$8,27 *$} & \multirow{2}{*}{2} & 1 & Eş yok & Düşük & 133,41 & 58 \\
\hline & & & 2 & Eş çalışıyor veya çalışmıyor & Yüksek & 143,76 & 290 \\
\hline \multirow{2}{*}{ 4. Vekalet Görevi } & \multirow{2}{*}{$5,75^{*}$} & \multirow{2}{*}{2} & 1 & Her zaman & Düşük & 127,5 & 18 \\
\hline & & & 2 & Hiç veya bazen & Yüksek & 142,08 & 330 \\
\hline 5. Görev & 1,07 & 4 & \multicolumn{5}{|c|}{ Göreve göre toplam iş doyumu farklı değildir. } \\
\hline 6. Eğitim & 3,39 & 4 & \multicolumn{5}{|c|}{ Eğitim düzeyine göre toplam iş doyumu farklı değildir. } \\
\hline 7. Yaş & 1,818 & 3 & \multicolumn{5}{|c|}{ Yaş gruplarına göre toplam iş doyumu farklı değildir. } \\
\hline 8. Cinsiyet & 0,32 & 1 & \multicolumn{5}{|c|}{ Cinsiyete göre toplam iş doyumu farklı değildir. } \\
\hline 9. Doğum Yeri & 3,33 & 6 & \multicolumn{5}{|c|}{ Doğum yerine göre toplam iş doyumu farklı değildir. } \\
\hline $\begin{array}{l}\text { 10. Toplam Hizmet } \\
\text { Süresi }\end{array}$ & 4,66 & 3 & \multicolumn{5}{|c|}{ Deneyime göre toplam iş doyumu farklı değildir. } \\
\hline 11. Görevde Geçen Süre & 3,09 & 4 & \multirow{2}{*}{\multicolumn{4}{|c|}{$\begin{array}{l}\text { Görevde Geçen Süreye göre toplam iş doyumu farklı } \\
\text { değildir. } \\
\text { Göre yeri sayısına göre toplam iş doyumu farklı değildir. }\end{array}$}} & \\
\hline 12. Görev Yeri Sayıs1 & 10,27 & 9 & & & & & \\
\hline
\end{tabular}

Tablo 5'ten görüldüğü gibi toplam iş doyumu katılımcıların yaptığı göreve, eğitim düzeyine, yaşına, cinsiyetine, doğum yerine, toplam hizmet süresine, görevde geçen süreye ve görev yeri sayısına göre farklı değildir. Buna karşılık çalış1lan birime göre 0,01 güven düzeyinde, medeni hal, eşin çalışma durumu ve vekalet görevi değişkenlerine göre de 0,05 güven düzeyinde anlamlı farklar göstermektedir. 
Katılımcıların çalış̧ıkları birime göre toplam iş doyum düzeyleri arasında 0,01 güven düzeyinde anlamlı fark vardır. Buna göre göreceli olarak, Yenice Orman İşletme Müdürlüğünde çalışan 32 deneğin toplam iş doyumu düşük olup, Ulus, Bartın, Zonguldak, Dirgine, Safranbolu, Karabük İşletme Müdürlüklerinde çalışan 257 deneğin toplam iş doyumu orta düzeyde, Ereğli ve Devrek Orman İşletme Müdürlüklerinde çalışan 59 deneğin toplam iş doyumu yüksek bulunmuştur. Yenice Orman İşletme Müdürlüğü ülkemizin doğal kaynaklarının başında yer alan ve orman emvali üretiminde milli gelire katkısı yüksek olan orman varlığıyla bilinmekte ve ormancılık çalışmalarının yoğun olduğu bir bölgedir. Yenice'nin nispeten küçük bir ilçe ve mahrumiyet bölgesi olması, iş yükünün fazlalığı, ağır çalışma şartları ve yönetim anlayışı gibi faktörlerin bunda etkili olduğu düşünülmektedir. Yenice'yi takip eden Ulus, Bartın, Zonguldak, Dirgine, Safranbolu ve Karabük Orman İşletme Müdürlüklerinde çalışanların toplam iş doyumu orta düzeyde bulunmuştur. Söz konusu orman işletmeleri de üretimde önemli bir paya sahiptir. Ancak bu işletmeler Yenice Orman İşletmesine göre daha ana yollara yakın ve nispeten gelişmiş durumdadır. Orman varlığ 1 ve iş kolunun çeşitliliğinin fazla olması çalş̧anlarda iş doyumunun etkisini göstermektedir. Daha gelişmiş ilçelerde ve ana yol üzerinde bulunan Ereğli ve Devrek Orman İşletme Müdürlüklerinde ise iş doyumu yüksek çıkmıştır.

Medeni hal değişkenine göre ankete katılanların toplam iş doyum düzeyleri arasında 0,05 güven düzeyinde anlamlı farklar vardır. Buna göre göreceli olarak evliler yüksek iş doyum düzeyine sahipken, bekârlar düşük doyum düzeyine sahiptir. Aynı şekilde eşin çalışma durumu değişkenine göre de katılımcıların toplam iş doyum düzeyleri arasında 0,05 güven düzeyinde anlamlı fark vardır. Yani evli olup da eşi çalışan da çalışmayan da yüksek iş doyumuna sahipken, bekârlar daha düşük iş doyum düzeyine sahiptir. Bu durumda Zonguldak Orman Bölge Müdürlüğü ve bağlı birimlerindeki evli çalışanlarda iş doyum düzeyinin yüksek olduğu görülmektedir. Ancak bu konuda Mersin Orman Bölge Müdürlüğ̈̈ ve buna bağlı orman işletme müdürlüklerinde yapılan bir çalışmada (Yılmaz vd., 2009); genel ve dışsal iş doyum faktörleri için bekarların en yüksek iş doyumuna, içsel iş doyumu faktörü için de evlilerin en düşük iş doyuma sahip olduğu saptanmıştır. Keza bu konuda yapılan bazı çalışmalarda (Yılmaz ve Koçak, 2008; Çok vd., 2017; Bölüktepe, 1993) ise, evliler ile bekarlar arasında iş doyumu açısından istatistiksel olarak anlamlı farkın olmadığı belirlenmiştir.

Ankete katılanların asli görevlerinin yanında vekaleten başka bir görev verilip verilmesine göre de toplam iş doyum düzeyleri arasında 0,05 güven düzeyinde anlamlı bir fark vardır. Dolayısıyla her zaman (sürekli) asli işlerinin yanında vekalet görevi olan çalışanlarda toplam iş düzeyi düşükken, bazen vekalet görevi olan veya hiç olmayan çalışanlarda toplam iş doyum düzeyi daha yüksektir. Bu durum çoğu kez vekalet görevi karşıllı̆ında ek ücret alınmadığı, çalışan üzerinde fazladan ek bir yük, stres ve sıkıntı oluşturduğu son derce normaldir.

\section{Sonuçlar ve Öneriler}

$\mathrm{Bu}$ çalışmada, Türkiye ormancılığında önemli bir yeri olan Zonguldak Orman Bölge Müdürlüğü ve bağlı birimlerinde çalışanların iş doyum düzeyleri ve bunu etkileyen faktörleri belirlenmiş, iş doyumunun bazı kişisel özelliklere (çalışılan birim, görev, eğitim, yaş, cinsiyet, medeni hal, eşin çalışma durumu, doğum yeri, toplam hizmet süresi, görevde geçen süre, görev yeri sayısı, vekalet görevi) göre farklılığını denetlenmiştir.

Zonguldak Orman Bölge Müdürlüğü ve bağlı birimlerinde çalışan toplam 348 kişi üzerinde, gerçekleştirilen anket çalışmasından elde edilen verileri değerlendirilmesi sonucunda, çalışanların iş doyumunu etkileyen en önemli faktörler; (1) Kararlara katılım ve saygınlık, (2) İşle bütünleşme, (3) Liyakate dayalı örgüt kültürü, (4) Örgütsel iletişim (bildirişme), (5) Vicdanen rahatlık, (6) Çalışma koşulları, (7) Ödül-takdir ve terfi olanağı olarak saptanmıştır. İş doyumunun \%\%67,40’1 bu faktörlere bağlıdır. Yönetim süreçlerinde bu faktörlere dikkat edilmesi hem iş doyumunu hem de kurumsal başarıyı artıracaktır. Ayrıca çalışanların orta düzeyde iş doyumuna sahip oldukları ve toplam iş doyumunun görev yapılan birime, medeni hale, eşin çalışma durumuna ve vekalet göreve göre istatistiksel olarak anlamlı fark gösterdiği, buna karşıllk görev, eğitim, yaş, cinsiyet, doğum yeri, toplam hizmet süresi, görevde geçen süre ve görev yeri sayısına göre anlaml bir fark göstermediği belirlenmiştir. Her ne kadar Türkiye'de ormancılığında bazı iş doyumu çalışmaları yapılmış olsa da, Zonguldak Orman Bölge Müdürlüğü ve bağlı birimlerinde daha önce böyle bir çalışma yapılmamıştır. Bu nedenle sonuçlarının uygulamaya ve sürdürülebilir orman kaynakları yönetimine katkı sağlama potansiyeli yüksektir.

Çalışmada ulaşılan sonuçlara ve anket formunun üçüncü bölümünden (Öneriler ve Yorumlar Bölümü) elde edilen bilgilere dayanarak Zonguldak Orman Bölge Müdürlüğü ve bağlı birimlerinde çalışanların iş doyumunun artırılması, daha verimli çalışmaları ve başarılı olmaları için aşağıdaki değerlendirmeler ve öneriler yapılmıştır:

1. İş yeri çalışma koşulları ve işle ilgili olanaklar/donanımlar (personel, araç-gereç, teçhizat, elbise vb.) yeterli ve kaliteli olmalıdır. 
2. Yönetim anlayışı liyakate dayalı olmalı, adil ve objektif kriterlere bağlı bir performans ölçüm ve ücretlendirme sistemi uygulanmalıdır.

3. Kişinin yaptığı işe saygı duyulması, topluma faydalı olduğuna inanması ve yaptığı işten kendini vicdanen rahat/huzurlu hissetmesi sağlanmalıdır.

4. Çalışan personelinin işini sevmesini sağlayacak ve performansını artıracak düzenlemeler (ödül, takdir, prim, terfi, sosyal hak vb.) bulunmalıdır.

5. Ast ve üst ilişkilerinde iletişim kanallarının açık olmalı ve etkili bir yönetim bilişim sistemi kurulmalıdır.

6. Çalışan personelin moral ve motivasyonu yüksek tutulmalıdır. Bunun için üstlerin çalışanlarla iyi diyalog kurması ve onların çeşitli sorunlarıyla (sağlık vb.) ilgilenmesi gerekmektedir.

7. Yöneticilerin adil olması, astlarına karşı saygılı davranması, yöneticilik ehliyetinin olması ve insan psikolojinden anlaması gerekmektedir.

8. Çalışanların yaptığı işlerle ilgili olarak karar alma ve uygulama yetkisi ve esnekliği bulunmalıdır.

9. Çalışanın işinde kendini özgür hissetmesi, yeteneğine ve kadrosuna uygun işlerde çalışması ve işle bütünleşmesi sağlanmalı ve düzenli olarak eğitilmelidir.

10. Çalışanlar iş ve aile yaşamlarını, sosyal ve kültürel faaliyetlerini dengeli şekilde yürütecek bir iş yoğunluğuna sahip olmalıdır.

11. Çalışanların işiyle ilgili faaliyetleri esnasında karşılaştıkları herhangi bir anlaşmazlık veya dava durumunda idare ve üst yönetimler tarafindan hukuksal destek sağlanmalıdır.

12. Görevde yükselme ve yer değiştirmede liyakate ve performansa dayalı bir sistem uygulanmalıdır.

13. Rotasyon uygulamalarının etkinliği analiz edilmeli, verimli çalışmayı ve iş doyumunu artıracak yeni bir düzenlemeye gidilmelidir.

14. İş yerinde toplumsal değer yargılarına, insan haklarına ve hukuka bağlı yerleşmiş bir örgüt kültürü oluşturulmalıdır.

15. Çalışanlar arasında sosyal ilişkilerin ve iletişimin artırılmasının yolları aranmalıdır.

16. Yapılan iş ve alınan ücret arasında denge ve adalet sağlanmalıdır.

17. Çalışanların mesai ücretleri düzenlenmeli, sosyal ve özlük hakları iyileştirilmelidir.

18. Çalışanlara çok zorunluluk olmadıkça vekalet görevi verilmemesi, vekalet görevi verilmesi halinde ise ek ücret ödenmesi sağlanmalıdır.

19. Çalışanlar arasında iş dağılımı liyakate dayalı olarak dengeli bir şekilde yapılmalıdır.

20. İş yerinin ve kurumun sosyal imkânlarından çalışanlar eşit düzeyde yararlanmalıdır.

21. Çalışanların bilgilendirilmesi ve hizmet içi eğitim çalışmalarına gereken önem ve özen gösterilmelidir.

22. İş yerinde cinsiyet ayrımı yapılmamalı ve herkes disiplin çerçevesinde birbirlerine daha saygılı davranmalıdır.

\section{Teşekkür}

Bu çalışma Bartın Üniversitesi Bilimsel Araştırma Projeleri Komisyonu tarafindan desteklenen 2018-FEN-A-008 kodlu bilimsel araştırma projesinden ve aynı proje kapsamında yürütülen "Zonguldak Orman Bölge Müdürlüğü Çalışanlarının İş Doyum Analizi” adılı bir Yüksek Lisans Tez çalışmasından üretilmiştir. Çalışmanın belirli bir k1smı 11-14 Nisan 2019'da Kastamonu'da düzenlenen “2nd International Congress on Engineering and Life Science “ICELIS 2019” Kongresine sözlü bildiri olarak sunulmuştur.

\section{Kaynaklar}

1. Akkamış, O. (2010). İlköğretim I. ve II. Kademe Öğretmenlerin İş Tatmini Üzerine Bir Değerlendirme. Yeditepe Üniversitesi Sosyal Bilimler Enstitüsü, İstanbul.

2. Aksu, G., Acuner, A. M., Tabak, R. S. (2002). Sağlık bakanlığı merkez ve taşra teşkilatı yöneticilerinin iş doyumuna yönelik bir araştırma (Ankara Örneği). Ankara Üniversitesi Tıp Fakültesi Mecmuası, 53(4), 271282.

3. Akyüz KC, Koçak S, Balaban Y, Yıldırım İ, Gedik T. (2011). Çalışanların iş tatmin düzeylerinin incelenmesi (Muğla Orman Bölge Müdürlüğü örneği). SDÜ Orman Fakültesi Dergisi, 12, 20-26.

4. Bennet, S., Bowers, D. (1977). An Introduction to Multivariate Techniques for Social and Behavioural Sciences. ISBN 033318277 4. The MacMillan Press, London, 149 pp.

5. Bozkurt, A., Daşdemir, İ., Karakaya, S., Şahin, H. A. (2018). Sakarya ili kavak üreticilerinin iş doyumunu etkileyen faktörler. Journal of Bartın Faculty of Forestry, 20(3), 609-617. DOI: 10.24011/barofd.461799.

6. Bölüktepe, E. F. (1993). Kamu Örgütlerinde İş Tatmini. Atatürk Üniversitesi. Sosyal Bilimler Enstitüsü. İşletme Anabilim Dalı, Erzurum. 
7. Büyüköztürk, Ş. (2015). Sosyal Bilimler İçin Veri Analizi El Kitabı: İstatistik, Araştırma Deseni, SPSS Uygulamaları ve Yorum. 21. Baskı, Pegem A Yayıncılık, Eğitim Danışmanlık Hizmetleri Tic. Ltd. Şti., ISBN 978-975-6802-74-8, Ankara, 213 s.

8. Çıtak M. A., Koldere, Y., Ünsar, S., Ergin, G, (2008). İstanbul ilinde görev yapan kamu ve özel ilköğretim öğretmenlerinin tatmin düzeylerinin belirlenmesine yönelik bir araştırma. Trakya Üniversitesi. Sosyal Bilimler Dergisi, Aralık, Cilt: 10, Sayı: 2.

9. Çok, N., Göksu, E., Doğaner, A., Kalkan, B., Güneş, Ö. (2017). Elazı̆̆ Orman Bölge Müdürlüğü çalışanlarının iş doyumu ve bazı bireysel özelliklerinin iş doyumuna etkisi. Turkish Journal of Forest Science, 1(2) 2017, 155-168.

10. Daşdemir, İ. (1996). Orman İşletmelerinin Başarı Düzeylerinin Belirlenmesi (Kuzeydoğu Anadolu ve Doğu Karadeniz Bölgesi Örneği). Orman Bakanlığı Doğu Anadolu Ormancılık Araştırma Müdürlüğü, Teknik Bülten No: 1, ISSN 1300-9478, 162 s., Erzurum.

11. Daşdemir. İ. (1998). Devlet Orman İşletmelerinin Yönetsel ve Örgütsel Boyutlarının Belirlenmesi. Orman Bakanlığı Doğu Anadolu Ormancılık Araştırma Müdürlüğü, Teknik Rapor No:3, ISSN 1300-9486, 70 s., Erzurum.

12. Daşdemir, İ. (2019). Bilimsel Araştırma Yöntemleri (2. Basım). Nobel Akademik Yayıncılık ve Danışmanlık Tic. Ltd. Şti., Yayın No: 1536, ISBN 978-605-320-442-8, Ankara,210 s.

13. Davis, K. (1981). Human behavior at work (Sixth Edition). New Delhi: TATA Mc Graw Hill Publishing Company Ltd.

14. Eren, E. (1996). Yönetim ve Organizasyon. Beta Yayın No: 4, İstanbul, 621 s.

15. İncir, G. (1990). Çalı̧̧anların iş doyumu üzerine bir araştırma. MPM Yayın No: 401, Ankara.

16. Kalıpsız, A. (1988). İstatistik Yöntemler. İstanbul Üniversitesi Orman Fakültesi Yayın No: 3522/394, İstanbul, $558 \mathrm{~s}$.

17. Mucuk, İ. (1978). İşletmelerde Modern Bir Araştırma Tekniği Olarak Faktör Analizi. İstanbul Üniversitesi Doçentlik Tezi, İstanbul.

18. Özdamar, K. (2002). Paket Programlar ile İstatistiksel Veri Analizleri (4. Baskı). ISBN 975-6786-00-7, Kaan Kitabevi, Eskişehir, 686 s.

19. Tosun, M. (1981). Örgütsel Etkililik. TODAIE Yayın No: 196, Ankara.

20. Yılmaz, E., Koçak, Z. (2008). Doğu Akdeniz Ormancılık Araştırma Müdürlüğü Çalışanlarına Yönelik İş Doyumu Araştırması. Çevre ve Orman Bakanlığı Yayın No: 364, DOA Yayın No: 48,Çeşitli Yayın No: 8, Tarsus, $56 \mathrm{~s}$.

21. Yılmaz, E., Daşdemir, İ., Karabulut, S., Koçak, Z., Polat, O. (2009). Orman Genel Müdürlüğü Taşra Teşkilatı Çalışanlarının İş Doyumunu Etkileyen Faktörler, Mersin Orman Bölge Müdürlüğü ve Buna Bağlı Orman İşletme Müdürlükleri Örneği. Çevre ve Orman Bakanlığı Yayın No: 387, DOA Yayın No:52, Teknik Bülten No:30, Tarsus, $65 \mathrm{~s}$.

22. ZOBM (2017). Zonguldak Orman Bölge Müdürlüğü 2017 Yılı Çalışma Programı. Zonguldak. 